\title{
The Analysis of Teaching Writing to English Young Learners (EYL) through a Movie: An ICT Perspective
}

\author{
Paramita Kusumawardhani ${ }^{1}$, Nurhayati ${ }^{2}$ \\ ${ }^{1}$ University of Bina Sarana Infromatika Jakarta, Indonesia \\ paramita.pmi@bsi.ac.id \\ ${ }^{2}$ University of Bina Sarana Informatika, Jakarta, Indonesia \\ nurhayati.nhi@bsi.ac.id
}

\author{
Cara Sitasi: \\ Kusumawardhani, P., \& Nurhayati. (2019). The Analysis of Teaching Writing to English Young Learners \\ (EYL) through a Movie: An ICT Perspective. Wanastra, 11(1), 25-34.
}

\begin{abstract}
This research has a purpose about how to use a movie to improve the learners', especially English Young Learners', writing skills. EYL has special characteristics that also need special approach and method in teaching. The development of technology has made some changing in teaching learning activity. Technology is one of the teaching aids which are now commonly used. It can be used to teach not only to adult but also to children. Movie, as a part of the development of technology, can be used to improve the learners' writing skill. The participants of this research are English Young Learners (EYL) in of the English Course at Gading Serpong, Tangerang. Descriptive qualitative was used as the method of the research and the English Young Learners' (EYL) story paper are used as the instruments of the research. The results of the research are: (1) Most learners were excited when they are asked to watch a movie; (2) Learners who have good writing skill could retell the story well, and (3) Learners who are not really master in writing, got some difficulties in retelling the story in written.
\end{abstract}

Keywords: Technology, ICT, Movie, Writing Skill, English Young Learners (EYL)

\section{INTRODUCTION}

Technology has entranced into almost in every home and schools. It makes the educators consider the way of its usage in education. It also makes the changing of the way of teaching learning. Technology has become common in usage and it cannot be excluded from teaching or learning. The activity of teaching learning has also got the impact of them. It means that not only the learners but also the teachers or educators should adapt with this changing. Teachers or educators who cannot implement the technology in their life, will "lose contact" with their students. Before teaching the learners or students about using technology in teaching learning process, the teacher or educators themselves have to invest technology as much as they can. By using technology, the information, references related to teaching learning activity are easily accessed both for teachers and learners.

One changing in teaching learning activity is the use of technology. Computer, video, movie, $\mathrm{CD}$, radio, etc can be used to help in teaching learning process. It is used in order to help the English learners, especially English Young Learners (EYL) to master English skills, especially writing skill. Besides, the use of technology can also enhance the learners' learning motivation and attention. Shyamlee (2012: 155) has analyzed the necessity of using multimedia technology to language teaching. $\mathrm{He}$ also recommends of using technology, especially multimedia technology in classrooms due to its positive effect on the teaching process without overlooking the teaching's role.

Technology is related to ICT. The term of 'ICT' is defined as "Forms of technology used for creating, displaying, storing, manipulating and exchanging information", (Meleisea, 2007; Nguyen \& Williams, 2012:3 cited in Tri \& Nguyen, 2014:33). The fastgrowing advance of information and communication technologies (ICTs) has made potential contributions to English language education for the past few decades. The ICTs can be applied in many teaching methods in order to ease the learners, especially the EYLs to learn English.

Technology can be used effectively as a cognitive tool as well as an instructional media. (Bruce and Levin, 2001) suggested that technology can be helpful in classroom settings by encouraging inquiry, helping communication, constructing teaching products, and assisting students' self expression. Muir-Herzig (2004:113) states that teaching and learning via technology engage learners in active 
situations of critical thinking to solve problems, share ideas with others and reflect what they have known. Classes which use technology shift from teachercentered to student-centered classes. Pitler et. al. (2007: 3) refers to the advantages of using technology in classes; they state that it enhances learning and understanding, and it encourages students to take active part in the learning process. It also has a positive impact to shift education from being teacher-centered to student-centered.

The use of ICT can also be implemented in writing skill. Learners can use blog or weblog, facebook, twitter, messenger, email or any platform social media to express their ideas or opinions through writing. By writing, the learners or students can encourage themselves to write better and more effective.

(Haswani, 2014) explained that since ICT's fast development, it has become a very important component which is now seen both as a necessity and an opportunity. UNESCO has stated in the Dakar Framework for action in April 2000, the use of ICT as one of the main strategies for achieving the EFA (Education for All) goal has been identified, (UNESCO-Ck.htm, 2005in Haswani, 2014). (Jung, 2006) also stated that both English and ICT have become essential literacy skills for a growing number of non-native speakers of English to ensure full participation in the information society. The use of ICT can add new dimension of literacy work when it is implemented in the teaching learning classroom activity, (Merchant, 2003).

(Pelgrum, 1996) stated that ICT: (1) encourages pupils to collaborate with one another and take responsibility for their own learning; (2) helps to nurture individual talent, independence and a strong sense of self worth and confidence; (3) encourages pupils to use their imaginations and promotes creativity, and (4) develops inquiry and communication skills and creates appropriate contexts for critical thinking, decision making, and problem solving activities.

Still based on (Pelgrum, 1996), he stated that ICT can help the learners or students to: (1) use a wide range of strategies to explore contrast, comparisons, and connections dynamically; (2) annotate text in innovative ways; (3) enrich or broaden the context of literacy study; (4) see texts in alternative versions; (5) use a wide range of analytical and critical techniques; (6) sort and process text and data quickly and efficiently; (7) order and arrange text and data experimentally, using combinations of word, image, sound and hypertext; (8) save, record, edit, and adapt their work quickly and efficiently; (9) retain evidence of the editing process so that it can be examined; (10) change the organizational structure and qualities of texts to suit different audiences and purposes; (11) compose multi-authored texts; (12) select from a wider range of audiences, throughout the world, and (13) exercise choice of medium and design while composing.

ICT can be implemented for four languages skills, such as listening, speaking, reading, and writing. Interactive teaching and learning activity can be improved by using ICT. The use of ICT in writing, for example using computer for writing, can improve the amounts of writing that the learners or students could perform. The use of ICT can also extend the learners or students ability to work independently and make connections among them.

But, not all kinds of technology can be used to improve the educational process. The teachers or educators should know what kinds of technology that can be applied in their teaching learning activity. Dunmire (2010: 3) states that not all kinds of technology are effective to improve the educational process.

Based on the explanations above, technology is created to ease human's life. Technology can be used in teaching or learning activity. It can be used to enhance the learners' English skills, such as listening, speaking, reading and writing. Technology then is expanded into ICT which is meant to be implemented in every aspects such as education, especially English lesson. Web sites, computers programs, presentation software, electronic dictionaries, chatting and emails, CDs and video clips are kinds of technology which can be used in teaching learning activity in the classrooms. The application of the technology depends on the English skills that are going to teach, the condition in the classrooms and also the learners' ability.

\section{The Nature of Movie}

There are many barriers in learning English, such as poor comprehension, limited vocabulary, slow reading, bad grammar, nonexistent conversational skills. Many language instructors, school designers, educators, teachers, lecturers are still investigating the way of teaching English to EYL. They keep investigating the way of teaching English to EYL effectively. There are also many strategies and methods that can be implemented to facilitate and to improve the EYL's mastery of English skills and movie are one of them. Movie can help the English learners, especially EYL to improve their English skills. Movie gives original language input and a stimulate framework for classroom discussions. They 
also provide a realistic view of the language and culture providing insights into the reality of life of native English speakers (Florence, 2009). By using movie, as one of the teaching media, English skills such as listening, speaking, reading and writing can be improved. Movies can become an integral part of the curriculum due to their significant effect on the development of the basic language skills: reading, listening, speaking, and writing, (Baratta \& Jones, 2008; Martín \& Jaén, 2009; Ismaili, 2013; \& Rokni \& Ataee, 2014; Yaseen \& Shakir, 2015). The learners' academic writing can also be reached by implementing a movie as a teaching tool. The "visuality" of movies can facilitate comprehension and understanding for the language learners in an ideal visual context, which makes it an effective language-teaching tool, (Khan, 2015). Still based on her, movie gives a variety of methods and resources for not only teaching the target language but also helping the learners to improve their listening and communicative skills.

There are some previous findings of using movie to teach English skills. Studies have also reported some advantages to the integration of movies into foreign language classes. For instance, movies can capture the students' attention towards the target language (Tognozzi, 2010); increase the students' motivation to learn the language (Ruusunen, 2011); supply good material to teach conversations (Martín \& Jaén, 2009); and improve the students' awareness of the target language culture (Zhang, 2013).

There are some benefits of using movie as a teaching tool. The learners' enjoyment and engagement with the movie are kinds of the benefits. The learners can share their understanding about the movie that they have watched. Based on (Kusumaningrum, 2015), using English movies can also be an attractive strategy to teach English. It can be used to teach listening, speaking and writing skill. Besides, it provides fun learning environment to teach grammar and vocabulary to learners. There are also some advantageous to gain by using movie as a teaching tool, they are:

1. English movies present more natural language, since the speakers in the movie are native speakers. Because of that, students can learn how topronounce the words appropriately.

2. English movies provide students a lot of contexts which can help them to learn how to use such expressions appropriately and contextually.

3. Students love watching movies. Fun learning environment gives them motivation to learn English as a Foreign Language.
4. Students can also learn English culture. While watching English movies, students can see cultural aspects included in the plot to illustrate social customs such as table manners to weddings and funerals, holidays, and celebrations. Thus, students' understanding in cross cultural communication is also improved.

There are also some disadvantageous related to use a movie as a teaching tool, they are:

1. While the movie is playing, students try to understand word by word instead of the main point of the movie. This may frustrate the students. Therefore, before playing the movie, teacher should explain clearly what the students have to do. Thus, students can enjoy watching the movie and learning English at the same time.

2. If the movie takes too much time to play, it is possible that students will get bored. To anticipate that, teacher should consider the length of the movie to watch or break the movie into several segments.

3. English movies can be American or British movies to give students different varieties of English. Different varieties entail different pronunciation and vocabulary. These differences may make students confused. Therefore, before or after watching the movie, teacher can explain or lead a class discussion about the English variety used in the movie.

4. The limited facilities in school can also pose an obstacle in teaching EFL using movies. If school has an English laboratory, then teacher can play the movie in the lab. However, if the school does not have an LCD or big screen TV, it is almost impossible to play the movie in the class. In addition, the activity might disturb the teaching and learning process of other classes.

Movie can also help on all counts. Since 1970s, educators experienced in using film as a teaching tool and it has been adopted by others, (Culkin, 1970: Maynard, 1969: 1971: 1977). Wegner (1977) was a pioneer in using this medium. His 1977 pamphlet described various film types and how to use them in the classroom. The learners' attention can be captured by using movies.

(Champoux, 1999:5) says, "Film can also be used to improve the learners' English skills, such as listening, speaking, reading and writing. (Kasper, 2002) demonstrates how screenings can be used to help develop writing skills. (Stewarts, 2006:1) says that vocabulary and listening comprehension are not the only skills improved by watching films; subtitles 
and closed captioning (dialogue and other sound information printed across the bottom of the frame) can help students increasing reading speed; films can also serve as the basis of writing assignments and oral presentations, especially when they are combined with the diverse. (Kasper, 2002) demonstrates how screenings can be used to develop writing skills.

(Masruddin, 2015: 242) said, "The using of technology as media in EYL classroom is very helpful. Furthermore, media technology can increase the students' interesting in learning process. Movie as a one of the kind of modern technology, it can be used as a good media since it is an enjoyable things for students".

Movie is one of the media that can be used as the teaching tools. By using movie, the EYL can learn about listening, speaking, reading and writing. The use of movie is related to technology. Technology has also used in education, especially in English education. It gives some influences in teaching method. It attracts the learners, especially English Young Learners (EYL) to learn English. The EYLs become more excited in learning English. Although some debates regarding to the effectiveness of technology have existed (Kleiman, 2004; Kozma, 1994), most researchers agree that technology can be used effectively as a cognitive tool as well as an instructional media. Technology can also be helpful in classroom settings by encouraging inquiry, helping communication, constructing teaching products, and assisting students' self-expression. (Kramsch \& Thorne, 2002) explained that the use of technologies provides learners with unprecedented opportunities to practice English and involve themselves in authentic environments of language use. The use of technology in various fields has been so successful and beneficial for teachers to reach some particular goals especially in education and for those who are learning a foreign language and literature, (Amiri, 2012:103).

So based on the theories above, movie is as a part of technology and one of the teaching tools that can be used to facilitate, encourage and improve the learners or students skills, such as listening, speaking, reading, and writing.

\section{The Nature of Writing}

The four languages skills and components should be known by the learners or students in learning English. It is very important for the learners or students, especially EYL to be able to write in English for their future life. Informal writing can be used as a start to learn to write, and ICT can be used to accommodate this.

Writing is the most difficult part in English subject as what it is said different from what it is written. (Ron White and Valerie Ardnt, 2011) stated that writing is far from being a simple matter of transcribing language into written symbols; it is a thinking process in its right. So, before the learners starting to write an English composition, they should master the English pattern correctly.

Writing is one of the skills in learning English. Writing skill is related to the learners' competence. It emphasizes on writing ability such as the production of a variety of genres and rhetorical features, but also including language-specific abilities like the use of a range of vocabulary and syntactic structures. Some learners, especially EYL have difficulties to express their ideas through writing. The difficulties are sometimes about choosing the topic of their writing. Therefore, they need some helps to find out the inspiration about what to write so they can express their ideas through writing easily. A good technique in writing should be chosen to ease the teaching learning process.

Writing can be said well if it can give information or messages clearly and creates effective verbal dialogue to readers. It aims to give point of view of the ideas in text where it organizes in different way of writing such as narration, description, exposition, and argumentation. When students write a paragraph, they try to explore what they are thinking in mind, and they also concern with the language, meaning, and the structural of context related to English language acquisition as second or foreign language.

Writing must be related to the content; the language and grammatical rule are related to writing. They should be done well in order to avoid misunderstood so the learners have to use correct sentences by creating a well written text and giving attention to the arrangement of words their composition to express their idea and to give the value of the writing to readers.

Writing is seen as a product constructed from the writer's command of grammatical and lexical knowledge, and writing development is considered to be the result of imitating and manipulating models provided by the teacher. For many who adopt this view, writing is regarded as an extension of grammar-a means of reinforcing language patterns through habit formation and testing learners' ability to produce well-formed sentences.

Developing writing is related to the writer's knowledge of language and writing exposure and 
writing process is the way the writers give their ideas and messages to readers in the form of text. Various ways of writing such as narration, description, classification, comparison and contrast, argumentation and etc. can be used to express or share the writers' ideas. Here are some ways to express and share the writers' ideas, (1) Narration. It is a basic writing strategy for presenting past event or activities. It can be used for a variety of purposes such as to illustrate and support ideas with anecdotes, to entertain readers with revealing stories, to analyze causes and possible effects with scenarios, and to explain procedures with process narrative; (2) Description. It is a strategy used to create a dominant impression. For example, describing a place in order to set a scene and make readers aware of its atmosphere and to describe people to show a kind of person's performance; (3) Classification. It aims to classify number of items or ideas into a small number of classes. In a classification of paragraph, it is important to set up adequate categories and define what goes into categories; (4) Comparison and contrast are to compare similar aspects or to contrast different aspects of two subjects, people or things, and (5) Argumentation. It is to argue ideas or opinion by giving some argues to proof the concept or research. A good paragraph must give readers complete information and unified by a controlling idea. It is organized form and can be understood what the paragraph is going to be about.

Based on the theories above, it can be concluded that there are some kinds in writing, such as narration, description, classification, comparison and argumentation. Writing is the most difficult part in learning English as it needs to master all English aspects, such as grammar, vocabulary, spelling, punctuation, etc to make a good writing. They are needed in order to avoid misunderstanding between the writer and the readers or between the teachers and the learners.

\section{The Nature of EYL}

There is a phenomenon in learning English. Learning English has started in the early age. It has happened since the second half of the century. It is also happened because now English is used in order to face the global demand which emphasis on the need for communication skills.

The process information between EYL and adult is different. Children, start from an early age, begin to sort out words involving concrete subjects. It happens when EYL study about vocabulary. They need objects which they can see or handle. EYL do not comprehend abstract subjects such as grammar.
Bourke (2006: 280) notes that young learners don't have a concept of ideas such as parts of speech, discourse or phonology.

(Cameron, 2001:1) says that:

Some differences are immediately obvious: children are more enthusiastic and lively as learners. They want to please the teacher rather than peer-groups. They will have a go at an activity even when they don't quite understand why or how. However, they also lose interest more quickly and are less able to keep themselves motivated on tasks they find difficult. Children do not find it as easy to use language to talk about language; in other words, they do not have the same access as older learners to meta-language that teachers can use to explain about grammar or discourse. Children often seem embarrassed than adults at talking in a new language, and their lack inhibition seems to help them get a more native-like accent.

EYL's characteristics are necessary to be known and understood by EYL's teachers. It is done because it will influence many aspects in teaching English to EYL. The aspects are: teaching style, methods, teaching materials, lesson plan and the way of getting along with them. The aspects becomes important to be understood by EYL's teachers as EYL usually want to know about everything, as Pinter (2006) said that young learners have a great curiosity to try new things and to explore concrete to abstract things. Harmer (2001) also explains that young learners get their understanding not only from explanation but also from what they see and hear, learn when they have a chance to touch and interact with (experience it).

(Juhana, 2014:43) said that teaching English as a foreign language to young learners needs special approach since young learners have special characteristics. It is stated that the improvement of abilities to learn foreign language is started from the early age. Teaching EYL needs interesting materials. It is done in order to get the EYLs' attention as EYLs' knowledge, especially about language, is limited. (Slattery and Willis, 2001) said that young learners have a quite short attention span and are easy to get bored. So, comprehending the EYL's characteristics and selecting the suitable materials are important in order to be successful in teaching EYL.

Based on the theories above, it can be concluded that English learners, especially EYL can improve their writing skills through watching a movie. It can be said as EYL tends to see the pictures than read a book, a novel, a comic, etc. Educators should also select the materials which will provide the 
knowledge that is most applicable to their classroom as EYL have special characteristics.

\section{RESEARCH METHOD}

The data for this research was taken from the learners' story paper and there were about 5 pieces of the learners' story paper used as the sample.

Descriptive method was used to do the research. There are three types of descriptive method, they are an observational method, case study method, and survey method. The observational method as a part of a descriptive method was used to take the data.

Descriptive method was used as (Best, 1974) explained that descriptive method is the method which tries to give the explanation about the symptoms relating to the recent situation. It consists

Here is the EYLs' Ferdinand Movie written stories. on the effort of giving the note, the analysis and the interpretation of the recent symptoms which have the characteristics as follows: try to give the fact, straight to the problem and the recent variables aren't manipulated by the researcher.

Identifying, classifying, analyzing and correcting were done as the procedures of the research. They were done in order to know about the advantageous and disadvantageous of using a movie for teaching writing for EYL.

\section{RESULTS AND DISCUSSION}

After doing some researches to the EYL, some findings related to the research are found. Most EYL watched the movie that they liked and most of them could retell the story well even there are still some grammatical errors on their written stories.

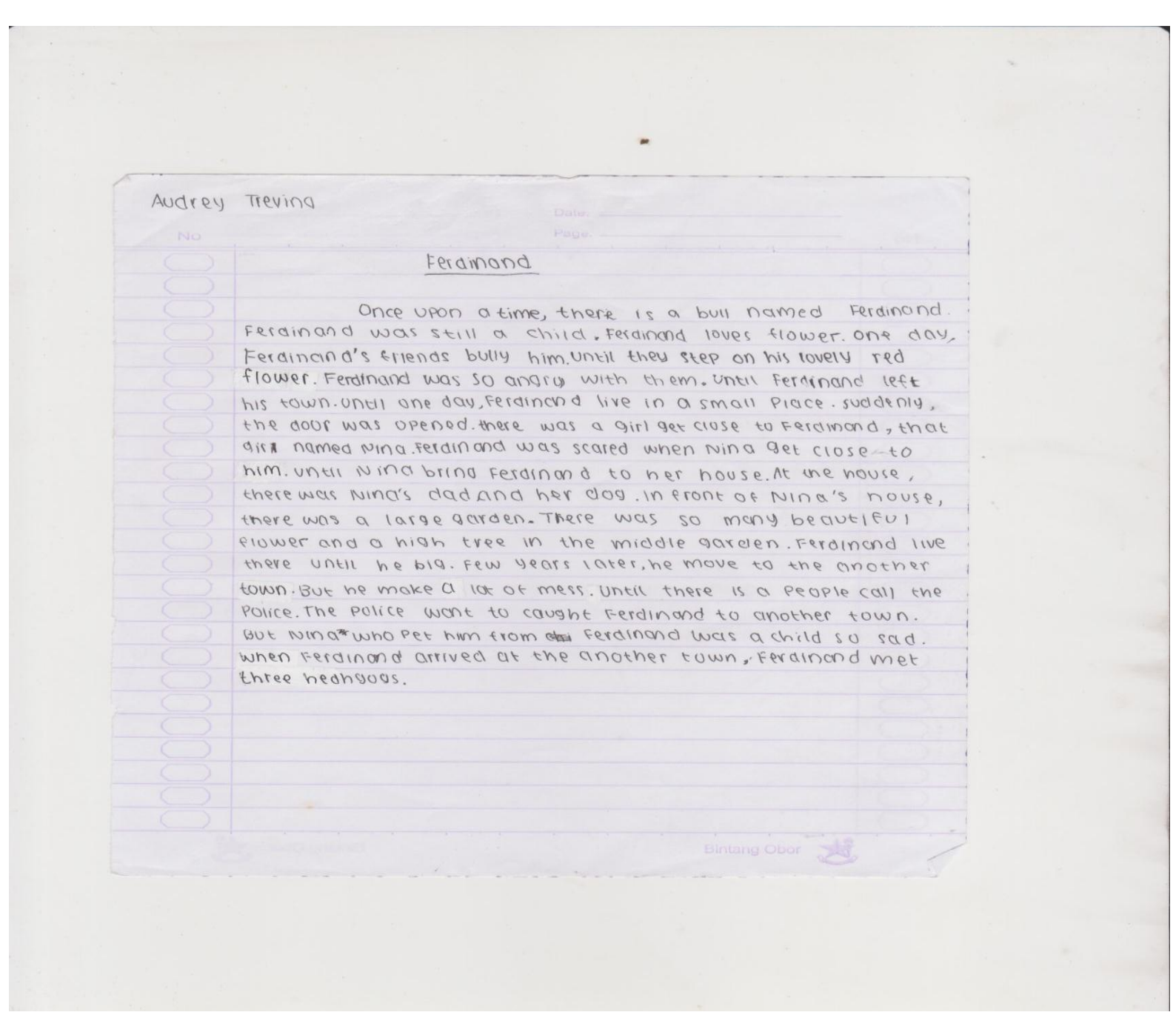

Picture 1. Audrey's Written Story 


\section{June $27^{\text {th }} 18$ (Retellingstory) Dave $M, H$ Wednesday$$
\text { Ferdinand }
$$

One apon of time, there was a little black bull that was nomed ferdinand, back then he was a cowar d be cause he doesn't like to fight. He likes flowers and his dad was a champion, but hefainted away and Ferdinandescaped the borm and wos found by little yirl named Nina. Over time, he grew up and went to a carnival but he ruined everything. So, he was sucsesfully captured back and to his barn. Then, he was partnered with a helping fermale goat, but she did not help to much. When he came back, his friends grew up to but not as big as Ferdina and they are still as mean. At night, Whizz's came and try to stead food but he let them go. The next day, they had a tournament and one of them failod and got chopped of. That right, ferdinand phannicel to escape the barn. with the Whiz2/s and everyone as well. Then, they went on the truck and was chased by the owner. Then, they arrived act. a city ard went crazy. Affer that, they tried to go on the train. But it didn't went well with Ferdinand because he was captured back and went to the tournament. He fought in the four nament and won and became famous. And they lived happily

Picture 2. Dave's Written Story 


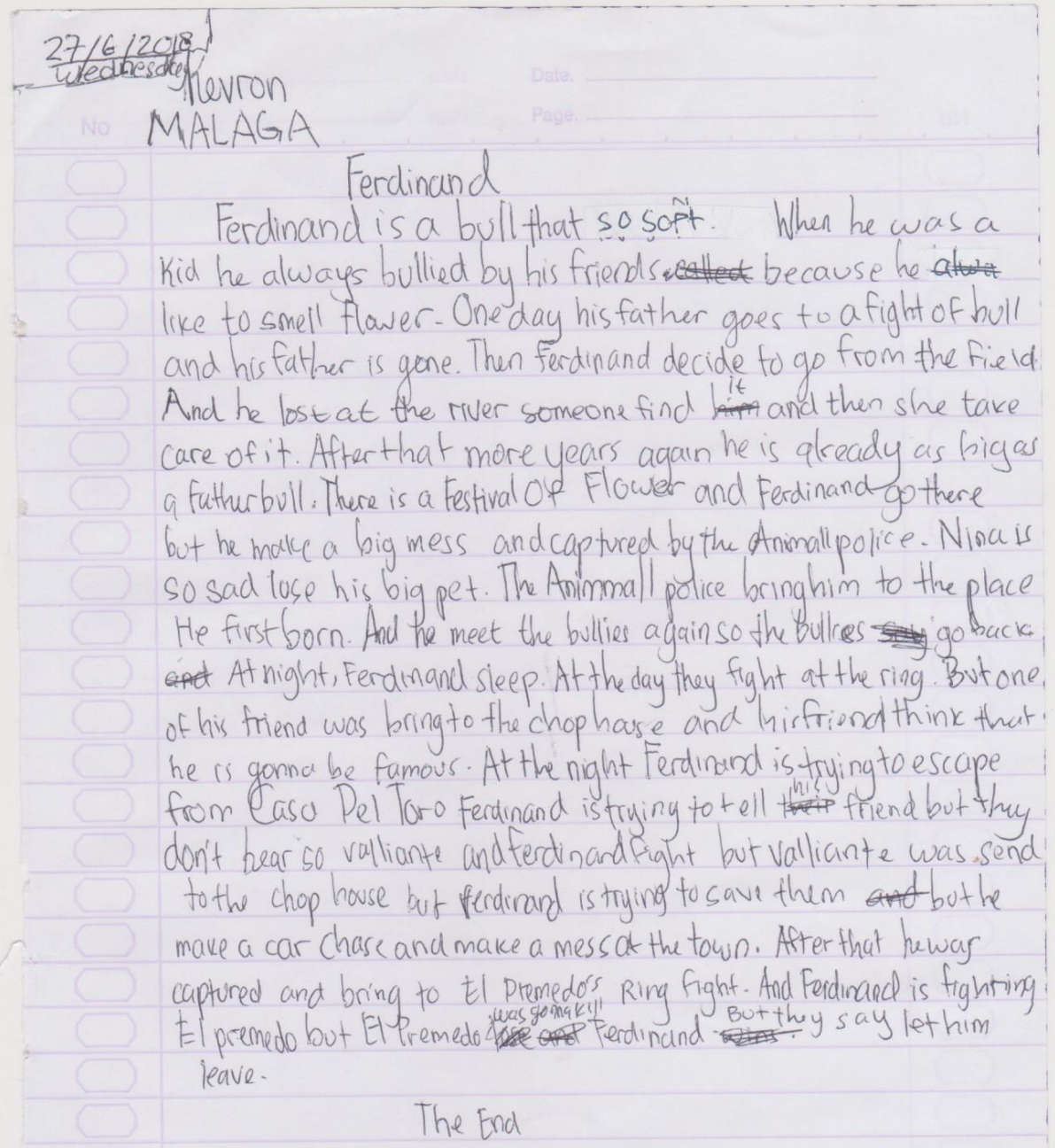

Picture 3. Kevron's Written Story 


\section{$27 \cdot 6 \cdot 2018$ \\ Wednesday \\ Ferdinand}

There's a huil and his dad is going to
chop. He go to his dad place but there's

soine prople want to catch him but he run fast

and go to the tran and those people can't

caten him. And then there's a girl find him and

adopt him. But one day the bull go out and

he make a mess. And the police casen him. And he

meet many friend One day he and ocher bull

fight. He win and the othere other buil lose.

The other buil a is going to chop but that

boil save him. One day they run and

that bull lost and he's ase going to tight.

E One of the people is yoing to rit

him but the awdience says "don't" So

he don't hit that buil. At the last, the

bul save and he come back to that gir
house.

Picture 4. Lois' Written Story 
Prisoil

\section{FERDINAND}

Once upon a time there was a little young bull called Ferdinand. He kept getting bullied by his friends as a flower loving bull. At that time, his father is shosen to the famous bull fight. But at night when he heard a truck he thought his father is back but his father was actually dead and so he ran away to go far but ended up lost until a farmer found him called Juan.In there saw Nina. On the time Ferdinand grew in that farm until the flower festival when he got caught and put back into the place he were when he uas a kid. And so the next day a famous bull fighter, El primero is here to pick the best bull. But Ferdinand doesn't don't want to fight. At the fight Guapo past out and the fight was a big mess. Sadly, Gapo got sent to the chop house and valiente Kept making fun of him. 位 night, the hedghoges helped him to escaped but on the way he saus many bull's horns and realize it is just a trap so when tries suarning the other but Valiente decided to push him and fight him but el prinero sausvaliente's hom break and had decided who then will took. Ferdinandwsaves Guaps and Valiente from the chop house and all escaped. But Ferdinand was capture to the final fight. At the final, Ferdinand refuce to fight. When El primero is about to kill him, the crout says to let him live and so he is safe. And so they live happily ever offer, The End.

\section{Picture 5. Prissil's Written Story}


Based on the pictures above, they showed that the learners could retell the story well even there were still some mistakes on their grammar such inconsistency of using the tenses. It means that a movie can also help the learners, especially EYL to improve their writing skill.

\section{CONCLUSION}

From the theories, findings and discussions above, it can be concluded that EYL have special characteristics that can make teachers provide suitable materials to be taught to them and teaching English for young learners should be appropriately conducted in order to be successful. Movies, as one of the teaching learning media, are powerful instructional tools which can help the learners, especially the EYL to improve their English skills, especially writing skill. By using a movie in improving English skills, there are some factors that can be acquired, such as vocabularies, grammar, listening, speaking, reading and writing.

\section{REFERENCES}

Amiri, Elsa. (2012). A Study of the Application of Digital Technologies in Teaching and Learning English Language and Literature. International Journal of Scientific \& Technology Research, 1(5), 103-107.

Baratta, A., \& Jones, S. (2008). Using film to introduce and develop academic writing skills among UK undergraduate students. Journal of Educational Enquiry, 8(2), 15-37.

Best, John, W. (2006). Research in Education. New Jersey: Prentice Hall.

Bourke, J. (2006). Designing a topic-based syllabus for young learners. ELT Journal, 60(3),

279-286.

Bruce, B., \& Levin, J. (2001). Roles for new technologies in language arts: inquiry, communication, construction, and expression. In J.Jenson, J. Flood, D.

Cameron, L. (2003). Challenges for ELT from the Expansion in Teaching Children. ELT Journal, 57, 105-112.

Champoux, Joseph E. (1999). Film as a Teaching Resource. Journal of Management Inquiry, 8(2), 240-251.
Culkin, J. M. (1970). Films Deliver: Teaching Creatively with Film. New York: Citation Press.

Dunmire, Ryan E. (2010). The Use of Instructional Technology in the Classroom: Selection and Effectiveness.

http://www.usma.edu/cfe/literature/dunmire_ 10.pdf.

Harmer, J. (2001). The Practice of English Language Teaching. England: Pearson Education Limited.

Haswani, Fahri. (2014). The Role of Technology in EFL Classroom. Indonesian Journal of English Education, Vol. 1(2), 107-118.

Ismaili, M. (2013). The Effectiveness of Using Movies in the EFL Classroom: A study conducted at South East European University. Academic Journal of Interdisciplinary Studies, 2(4), 121-132. http://dx.doi.org/10.5901/ajis.2012.v2n4p12 1.

Juhana. (2014). Teaching English to Young Learners: Some Points to be Considered. Asian Journal of Education and E-Learning, 2(01), 43-46.

Jung, Sei Hwa. (2006). The Use of ICT in Learning English as an International Language. http://Education.uci.edu/Person/warshauerin/docs/networksed.pdf.

Merchant, G. (2003). E-mail me your Thoughts: Digital Communication and Narrative Writing. Reading, Vol 37(3), 104-110. DOI: 10.1046/j.00340472.2003.03703003.

Kasper, L. (2002). The Imagery of Rhetoric: Film and Academic Writing in the DisciplineBased ESL Course. Teaching English in the Two-Year College, 28(1), 52-59.

Khan, A. (2015). Using Films in the EFL Classroomto Improve Communication Skills of Non-Native Learners. ELT Voices, Vol. 5(4), 46-52.

Kleiman, G. M. (2004). Myths and Realities about Technology in K-12 Schools: Five Years Later. Contemporary Issues in Technology and Teacher Education, Vol. 4(2), 248-253.

Kozma, R.B. (1994). Will Media Influence Learning? Reframing the Debate. Educational Technology Research and Development, Vol. 42(2), 7-19. 
Kusumaningrum, Maria Asumpta Deny. (2015). Using English Movie as an Attractive Strategy to Teach Senior High School Students English as a Foreign Language. LLT Journal, Vol. 18(1), 11-18.

Kramsch, C., \& Thorne, S. L. (2002). Foreign Language Learning as Global Communicative Practice. In D. Block and D. Cameron (Eds), Globalization and Language Teaching. London and New York: Routledge.

Martín, M., \& Jaén, M. (2009). Teaching conversation through films: A Comparison of Conversational Features and Collocations in the BNC and a Micro-Corpus of Movies. The International Journal of Learning, 16(7), 445-458.

Masruddin, M. (2015). Using Movie in Teaching Writing (A Classroom Action Research). Ethical Lingua: Journal of Language Teaching and Literature, 2(2), 241-249.

Maynard, R. A. (1969). The Social Studies and Media. The Social Studies Journal, 327-329.

Maynard, R. A. (1971). The Celluloid Curriculum: How to Use Movies in the Classroom. New York: Hayden Book Company, Inc.

Maynard, R. A. (1977). Classroom Cinema. New York: Teacher College, Columbia University.

Muir-Herzig, Rozalind G. (2004). Technology and Its Impact in the Classroom. Computers and Education. Vol. 42, 111-131.

Nguyen, Nhung Hong Thi, \& Tri, Dang Hoang. (2014). An Exploratory Study of ICT Use in English Language Learning among EFL University Students. Teaching English with Technology, 14(4), 32-46.

Pinter, A. (2006). Teaching Young Language Learners. London: Oxford University Press.

Pitler, Howard; Hubbell, Elizabeth R.; Kuhn, Matt. (2007). Using Technology with Classroom
Instruction that Works. http://thelearningweb.wikispaces.com/file/vie w/Using_Technology_with_Classroom_Instr uction_That_Works.pdf.

Rokni, S., \& Ataee, A. (2014). Movies in EFL Classrooms: With or without subtitles. The Dawn Journal, 3(1), 715-726.

Ron, White, and Valerie Ardnt. (2011). Process Writing. London: Longman Group.

Ruusunen, V. (2011). Using Movies in EFL Teaching: The Point of View of Teachers. Masters Thesis.

Shyamlee, Solanki D. (2012). Use of Technology in English Language Teaching and Learning: An Analysis. Medias and Culture IPEDR, Vol.33.

Slatery, M. and Willis, J. (2001). English for Primary Teachers. London: Oxford University Press.

Stewart, David M. (2006). Film English: Using Films to Teach English. Electronic Journal of English Education 24, 1-17.

Tognozzi, E. (2010). Teaching and Evaluating Language and Culture through Language. ITALICA, Vol. 87(1), 69-91.

Wegner, H. (1977). Teaching with Film. Bloomington, IN: The Phi Delta Kappa Educational Foundation

Yaseen, B., \& Shakir, H. (2015). Movies Effects on EFL Learners at Iraqi School in Kuala Lumpur. International Journal of Education and Literacy Studies, 3(3), 31-36. http://dx.doi.org/10.7575/aiac.ijels.v.3n.3p.3 1. Zhang, Q. (2013). The Impact of Film and Film-Based Activities on the Attitudes of English Speaking Secondary-School Students towardL2 Chinese. Creative Practices in Language Learning and Teaching, $\quad$ Vol. 1(2), 1-17. 